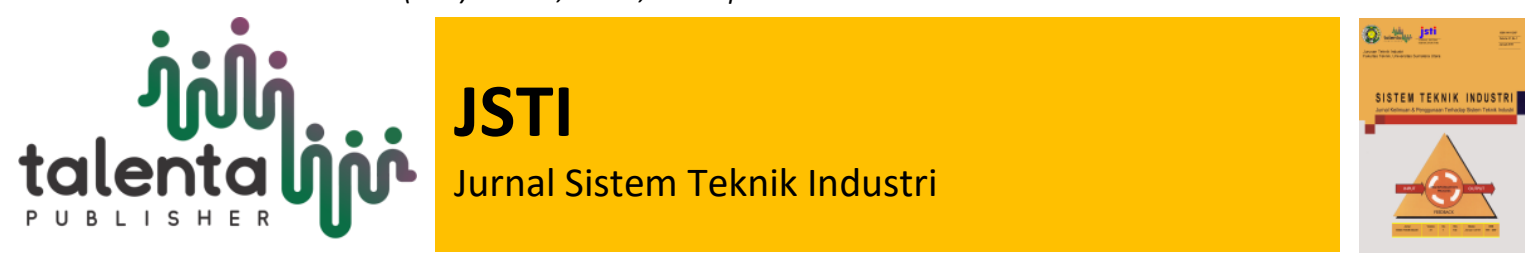

\title{
Evaluasi Produksi Minyak Mentah Gross Profit Worth(GPW), Margin,Proses Blending dan Kolaborasi Rantai Pasok
}

\author{
Meilita Tryana Sembiring 1, Elisabeth Ginting 1, Feby Sanna Sibarani 1 \\ ${ }^{1}$ Departemen Teknik Industri, Fakultas Teknik, Universitas Sumatera Utara. Medan, Indonesia
}

\begin{abstract}
Abstrak.Timur Tengah merupakan penghasil minyak mentah yang sebagian besar pendistribusiannya dilakukan di benua Asia. Berdasarkan data dari BP Statistical Review Of World Energy 2018, konsumsi energi Indonesia meningkat sebesar 5,0\%, yaitu 175,2 juta ton, yang merupakan peningkatan terbesar dalam lima tahun terakhir. Konsumsi energi berada di wilayah Jawa dan sekitarnya. PT. Unit Pengilangan Pertamina (RU) IV Cilacap memproses minyak mentah domestik dan impor minyak mentah sebagai bahan baku. Pemrosesan minyak mentah dipengaruhi oleh Gross Profit Worth (GPW) dalam minyak mentah yang diproduksi. GPW pada Agami -7,66 minyak mentah impor pada bulan Januari dan -6,45 pada bulan Februari. Margin diperoleh 1.046,04 pada bulan Januari. Sementara itu, berdasarkan harga minyak yang relatif mahal, maka hal tersebut diatasi dengan proses Blending dilakukan meningkatkan Octane Number (ON) dan mencari minyak mentah alternatif daripada minyak mentah impor. Dan masalah yang dialami pada realita di lapangan yakni kelebihan waktu bongkar muat yang disebut dengan Demurrage. Beberapa faktor di atas menunjukkan bahwa diperlukan inovasi dalam hal rantai pasokan dan energi alternatif dari penggunaan minyak mentah impor.
\end{abstract}

Kata Kunci:Gross Profit Worth; Margin; Simulasi Waktu Penyandaran; Kolaborasi Rantai Pasok

\begin{abstract}
The Middle East is a producer of crude oil which is mostly distributed on the Asian continent. Data is collected from Bp Statistical Review Of World Energy 2018, Indonesia's energy consumption increased by 5.0\%, which was 175.2 Million tons, which was the biggest increase in the last five years. The biggest energy consumption is in the area of Java and its surroundings. PT. Pertamina Refinery Unit (RU) IV Cilacap processes domestic crude oil and crude oil imports as raw materials. The processing of crude oil is influenced by Gross Profit Worth (GPW) in the crude produced. GPW on Agami -7.66 import crude in January and -6.45 in February. The margin obtained was 1,046.04 in January. Meanwhile, based on the relatively expensive oil price, the Blending process is carried out in increasing the Octane Number $(O N)$ and looking for alternative crude instead of imported crude. In the reality of distribution there are the Excess Laytime phenomenons which requires companies to pay rent penalties that is called Demurrage. Some of the above factors have made it necessary to have improved innovations in terms of supply chains and alternative energy from the use of imported crude oil.
\end{abstract}

Keywords:Gross Profit Worth; Margin; Berthing Time Simulation; Collaboration Supply Chain

Received 12 July 2019| Revised 26 July 2019| Accepted 26 July 2019

*Corresponding author at:Jl. Almamater Padang Bulan, Medan Baru, Medan City, North Sumatra 20222

E-mail address:meilita_tryana@yahoo.com,ir.elisabethginting@gmail.com,febysannasibarani@gmail.com 


\section{Pendahuluan}

Asia pada dasarnya melakukan proses pembelian produk yakni bahan baku minyak mentah yang berasal dari negara - negara penghasil minyak. Terdapat persepsi bahwa Asia harus membayar mahal untuk mendapatkan minyak mentah maka disebut dengan "Asia Premium" bagi setiap negara bagian yang terdapat di Asia. Asia khususnya Indonesia memperoleh minyak mentah yang berasal dari Timur Tengah yakni Kingdom of Saudi Arabia (KSA). Hasilnya KSA diharuskan untuk menurunkan harga dari minyak mentah dibandingkan dengan penghasil minyak yang berasal dari Eropa dan United States (US). Berdasarkan hal tersebut, maka dilakukan pengkajian ulang apakah pada persepsi "Asia Premium" masih dapat dipertahankan pada negara - negara bagian Asia khususnya Indonesia [1].

Telah menjadi hal umum bahwa Asia membayar harga yang lebih tinggi untuk mendapatkan minyak mentah yang berasal dari daerah Timur Tengah (Middle East Crude). Dikarenakan harga serta biaya transportasi yang lebih tinggi, maka produsen minyak khususnya pada bagian pemurnian (Refinery) mengalami kerugian dalam hal keuntungan yang diperoleh. Pembangunan kilang dilakukan dalam pengolahan minyak mentah dengan jenis dan harga minyak mentah yang bervariasi serta permintaan yang fluktuatif terjadi untuk produk olahan dari Refinery Unit. Hal tersebut mengharuskan kilang khususnya bagian produksi untuk mengurangi biaya bahan baku yang digunakan dalam penyulingan. Hal ini dicapai dengan melakukan pencampuran pada minyak mentah dengan jenis yang berbeda. Minyak mentah dengan jenis kualitas rendah dapat dibeli dengan biaya rendah [2].

Pencampuran dengan minyak mentah khususnya kualitas yang lebih baik dapat menghasilkan campuran minyak mentah yang bersifat optimal untuk diproses dengan tujuan untuk memperoleh biaya minimum. Indonesia terdiri atas kilang - kilang pemurnian yang tersebar di seluruh Indonesia. Kilang pemurnian terbesar berada pada Cilacap, Jawa Tengah. Kilang kilang tersebut disebut dengan Refinery Unit (RU). Bahan baku kilang yang terdapat di PT. PERTAMINA (Persero) RU IV Cilacap berupa crude oil yang didatangkan dari KSA sebagai negara penghasil minyak dan crude oil yang berasal dari dalam negeri (domestik) dengan menggunakan kapal-kapal tanker.PT. PERTAMINA (Persero) RU IV Cilacap mengolah crude untuk memproduksi Bahan Bakar Minyak (BBM), Non BBM, dan Petrokimia sangat diperlukan perencanaan yang tepat dan bernilai ekonomis agar proses produksi efektif yang diatur oleh bagian yang disebut dengan Refinery Planning and Optimization (RPO). RPO terbagi atas Refinery Planning, Supply Chain and Distribution, serta Budget and Performance. PERTAMINA (Persero) RU IV Cilacap memiliki beberapa unit kilang pengolahan yakni Kilang Fuel Oil Complex I, Fuel Oil Complex II, Lube Base Oil I, Lube Base Oil II, Lube Base Oil III, Kilang Paraxylene, Kilang Sulfur Recovery, dan Kilang Residual Fluid Catalytic Cracking (RFCC).PERTAMINA (Persero) RU IV Cilacap memiliki kapasitas sebesar 348.000 barrel/hari. 


\section{Metodologi Penelitian}

Penelitian dilakukan pada kilang PERTAMINA (Persero) RU IV Cilacap dengan menggunakan metode Gross Product Worth (GPW), Simulasi Berthing Time, dan Blending Component dengan menggunakan Volume serta Octane Number (ON). Lalu, dilakukan evaluasi dan usulan perbaikan pada PERTAMINA (Persero) RU IV Cilacap.

\section{Data dan Pembahasan}

Secara praktik internasional, terdapat tiga konfigurasi kilang yang berbeda yang biasanya digunakan oleh industri untuk menetapkan harga minyak mentah;

a.Model Kilang Sederhana seperti topping yakni minyak mentah dipisahkan menjadi produk yang relatif belum selesai, yaitu LPG, Nafta, Gasoil, dan bahan bakar sisa.

b.Model Hydro Skimming Refinery mirip dengan Simple Refinery Model dengan penambahan unit pembaharuan naphtha katalitik dan fasilitas desulfurisasi yang diperlukan untuk menyelesaikan produk, seperti Minyak Tanah dan Gasoil.

c.Composite Refinery Model adalah perwakilan konfigurasi wilayah di mana target minyak mentah akan dipasarkan. Wilayah Asia Pasifik menggunakan Singapura sebagai patokan untuk harganya karena pasarnya sangat likuid dan transparan.

Perhitungan dilakukan pada bulan Januari sampai dengan Februari tahun 2018. Berikut merupakan daftar harga produk dan harga crude domestic yang digunakan yakni sebagai berikut :

Table 1 Daftar Harga Produk

\begin{tabular}{llllll}
\hline Nama & \multicolumn{5}{c}{ Daftar Harga US\$ } \\
\cline { 2 - 6 } Produk & Januari & Februari & Maret & April & Mei \\
\hline LPG & 56,71 & 50,08 & 50,14 & 48,04 & 46,53 \\
Premium & 64,79 & 65,52 & 66,00 & 67,56 & 70,97 \\
Avtur & 82,63 & 87,64 & 86,07 & 86,86 & 91,66 \\
Solar & 76,19 & 77,78 & 76,30 & 79,78 & 78,44 \\
IFO & 60,14 & 59,86 & 56,88 & 58,25 & 67,20 \\
\hline
\end{tabular}

Table 2 Daftar Harga Crude Impor

\begin{tabular}{llll}
\hline \multirow{2}{*}{ No } & \multirow{2}{*}{ Nama Crude } & \multicolumn{2}{c}{ Harga Crude Impor } \\
\cline { 3 - 4 } & & Januari & Februari \\
\hline 1 & Agbami & 78,38 & 78,38 \\
2 & Arab Light Crude & 67,90 & 64,54 \\
3 & 1018 & 69,87 & 65,88 \\
4 & Eabinda & 78,71 & 78,71 \\
5 & Qua Iboe & 79,94 & 79,94 \\
6 & Saharan & 69,85 & 66,04 \\
\hline
\end{tabular}


Pada Crude Impor terdapat bagian produk yang disebut dengan Yield. Yield adalah bagian dari setiap produk olahan yang bila dikombinasikan dengan bahan bakar kilang dan residu akan berjumlah sama dengan jumlah barel minyak mentah. Titik referensi harga produk spesifik dipilih untuk setiap bagian hasil untuk menentukan nilai total minyak mentah. Biaya pemrosesan termasuk biaya pemurnian, pengiriman, dan elemen lain yang dikurangi untuk mencapai nilai bersih dari titik asal minyak mentah (netback).Setiap Crude menghasilkan jumlah yield yang berbeda untuk setiap produk yang dihasilkan.

\subsection{Perhitungan yield untuk masing-masing crude impor}

Crude terdiri atas kandungan - kandungan pada masing - masing produk dengan nilai yield yang berbeda - beda.

Table 3 YieldCrude Impor

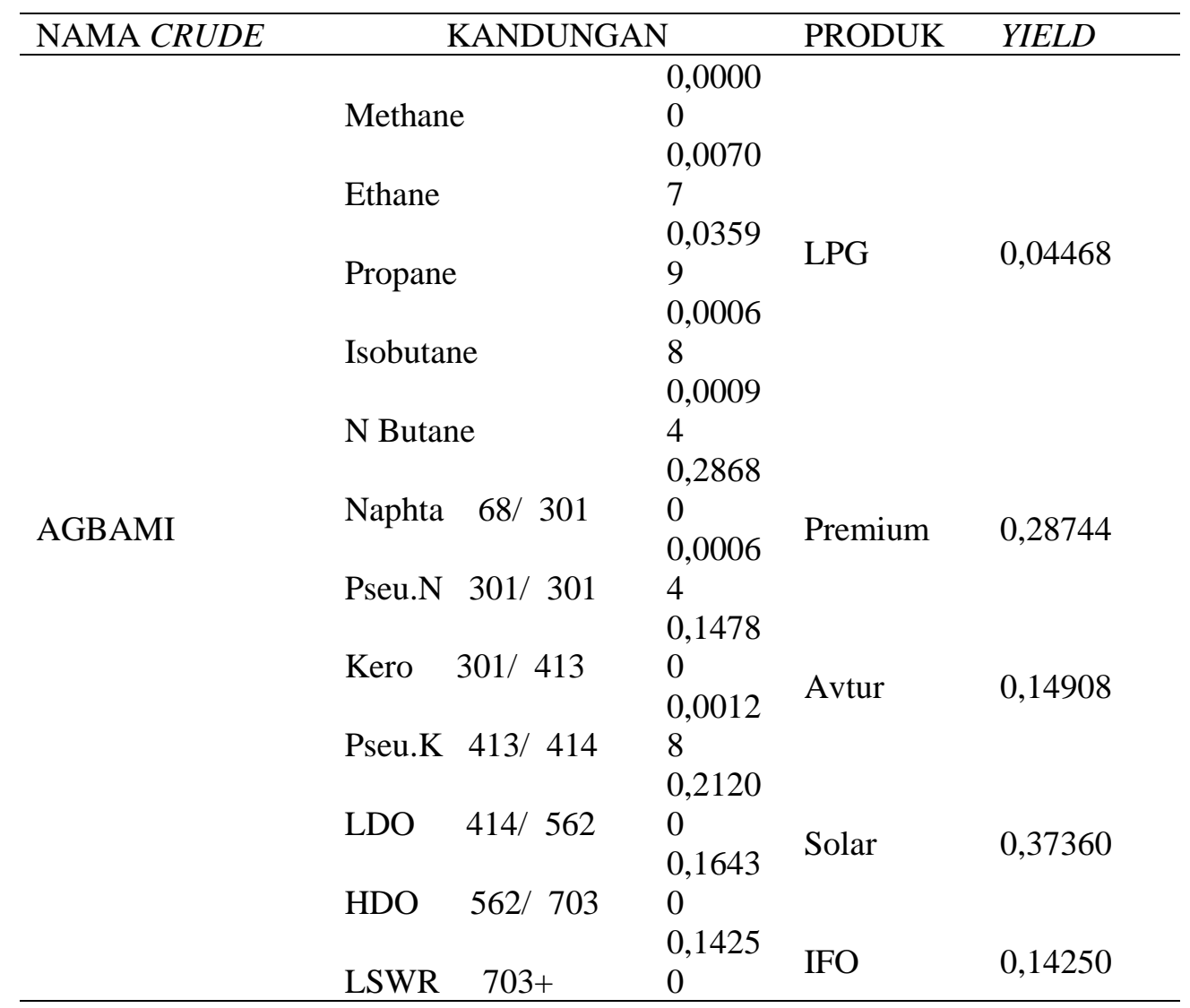

\subsection{Perhitungan Gross Product Worth pada Crude Impor}

Crude terdiri atas kandungan - kandungan pada masing - masing produk dengan nilai yield yang berbeda - beda. Gross product Worth (GPW) merupakan metode penghitungan nilai jenis minyak mentah tertentu yang didasarkan pada nilai produk olahan yang berasal dari minyak mentah tersebut. GPW tergantung pada harga produk yang berlaku dan proses pemurnian sederhana atau kompleks [3].

Rumus dari perhitungan Gross Product Worth sebagai berikut : 


$$
\mathrm{GPW}=\left(\frac{\text { Total Harga Produk }}{\text { Basis }}\right)-\text { Harga Crude }
$$

Perhitungan Gross Product Worth dihitung pada bulan Januari dan Februari 2018. Contoh perhitungan sebagai berikut:

Diketahui : Nama Crude

$$
=\text { AGBAMI }
$$

Basis

$$
=1000 \text { barrel }
$$

\begin{tabular}{|c|c|c|c|c|}
\hline \multicolumn{5}{|c|}{ AGBAMI CRUDE } \\
\hline Produk & Harga Produk & Yield & BBL & USD \\
\hline & & & & BARREL \\
\hline LPG & 56,71 & 0,04468 & 44,68 & $2.533,80$ \\
\hline Premium & 64,79 & 0,28744 & 287,44 & $18.623,24$ \\
\hline Avtur & 82,63 & 0,14908 & 149,08 & $12.318,48$ \\
\hline SOLAR & 76,19 & 0,37630 & 376,30 & $28.670,30$ \\
\hline IFO & 60,14 & 0,14250 & 142,50 & $8.569,95$ \\
\hline Jumlah & 340,46 & 1,00000 & $1.000,00$ & $70.715,77$ \\
\hline Harga Crude US\$/BBL & 78,38 & & & \\
\hline $\begin{array}{l}\text { Perhitungan GPW } \\
\text { US\$/BBL }\end{array}$ & $-7,66$ & & & \\
\hline
\end{tabular}

Harga Crude Bulan Januari $=78,38$ US $\$$

Table 4 Perhitungan Gross Profit Worth Crude Impor Bulan Januari

\begin{tabular}{|c|c|c|c|c|}
\hline \multicolumn{5}{|c|}{ AGBAMI CRUDE } \\
\hline Produk & $\begin{array}{l}\text { Harga } \\
\text { Produk }\end{array}$ & Yield & BBL & $\begin{array}{l}\text { USD } \\
\text { BARREL }\end{array}$ \\
\hline LPG & 50,08 & 0,04468 & 44,68 & $2.237,57$ \\
\hline Premium & 65,52 & 0,28744 & 287,44 & $18.833,07$ \\
\hline Avtur & 87,64 & 0,14908 & 149,08 & $13.065,37$ \\
\hline SOLAR & 77,78 & 0,37630 & 376,30 & $29.268,61$ \\
\hline IFO & 59,86 & 0,14250 & 142,50 & $8.530,05$ \\
\hline Jumlah & 340,88 & 1,00000 & $1.000,00$ & $71.934,68$ \\
\hline Harga Crude US\$/BBL & 78,38 & & & \\
\hline $\begin{array}{l}\text { Perhitungan GPW } \\
\text { US\$/BBL }\end{array}$ & $-6,45$ & & & \\
\hline
\end{tabular}

Table 5 Tabel Perhitungan Gross Profit Worth Crude Impor Bulan Februari

\subsection{Perhitungan Margin pada Crude Impor}

Rumus untuk perhitungan margin sebagai berikut:

$$
\text { MARGIN }=\left(\frac{\text { Total Harga Produk }}{\text { BBL GPW }}\right)-\text { Harga Crude }
$$

Perhitungan Margin dilakukan pada bulan Januari 2018 yakni sebagai berikut : 
Table 6 Tabel Perhitungan Margin Bulan Januari

\begin{tabular}{lllll}
\hline \multicolumn{5}{c}{ AGBAMI CRUDE } \\
\hline Produk & Harga Produk & Yield & BBL & USD BARREL \\
\hline LPG & 56,71 & 0,04468 & 44,68 & $2.533,80$ \\
Premium & 64,79 & 0,28744 & 287,44 & $18.623,24$ \\
Avtur & 82,63 & 0,14908 & 149,08 & $12.318,48$ \\
SOLAR & 76,19 & 0,37630 & 376,30 & $28.670,30$ \\
Propylene & 70,19 & 7,40000 & $1.054,50$ & $74.015,36$ \\
Gasoline & 72,56 & 54,57000 & $7.776,23$ & $564.242,89$ \\
LCO & 76,19 & 11,56000 & $1.647,30$ & $125.507,79$ \\
DCO & 60,14 & 11,71000 & $1.668,68$ & $100.354,11$ \\
OffGas & 54,79 & 5,59000 & 796,58 & $43.644,34$ \\
LPG & 56,71 & 19,12000 & $2.724,60$ & $154.512,07$ \\
Jumlah & 670,90 & 110,80750 & $16.525,38$ & $1.124 .422,37$ \\
\hline Harga Crude US\$/BBL & 78,38 & & \\
\hline Perhitungan Margin & $1.046,04$ & & \\
\hline
\end{tabular}

\subsection{Simulasi Berthing Timepada PERTAMINA (Persero) RU IV Cilacap}

Pendistribusian minyak mentah dilakukan pada masing - masing lokasi penyandaran yakni Single Point Mooring (300.000 DWT) dan Crude Island Berth (35.000 - 135.000 DWT). Pemindahan minyak dilakukan dengan menggunakan kapal - kapal tangki yang disewa untuk melakukan proses bongkar muat dengan ketentuan yakni sebagai berikut :

a. Operasi bongkar muat yang dilakukan pada Single Point Mooring (SPM), lay time allowed yang diperkenankan selama 30 jam dengan kapasitas minyak sebesar 400.000 barrel.

b. Operasi bongkar muat yang dilakukan langsung pada Crude Island Berth (CIB), lay time allowed yang diperkenankan selama 36 jam dengan kapasitas minyak sebesar 400.000 barrel sampai dengan 600.000 barrel.

c. Operasi bongkar muat yang dilakukan pada SPM, lay time allowed yang diperkenankan selama 48 jam dengan kapasitas minyak sebesar 900.000 barrel sampai dengan 1.000 .000 barrel.

d. Operasi bongkar muat yang dilakukan pada SPM, lay time allowed yang diperkenankan selama 60 jam dengan kapasitas minyak lebih dari 1.000.000 barrel [4].

Penyewaan dari kapal - kapal tersebut mengharuskan proses bongkar muat dilaksanakan tepat pada waktunya. Apabila proses tersebut lebih dari waktu yang telah disepakati, maka perusahaan wajib membayar kelebihan waktu dari proses bongkar muat yang disebut dengan Excess Lay Time (Demurrage) dengan rumus yakni : 
Table 7 Perhitungan Excess Laytime Bulan Januari

\begin{tabular}{|c|c|c|c|c|c|c|c|}
\hline \multirow{2}{*}{ Vessel } & \multirow{2}{*}{ Sandar } & \multicolumn{2}{|c|}{ Start Discharge } & \multicolumn{2}{|c|}{ Hose Disconnected } & \multirow{2}{*}{$\begin{array}{l}\text { Lay Time } \\
\text { (Jam) }\end{array}$} & \multirow{2}{*}{$\begin{array}{l}\text { Lay Time } \\
\text { Analysis }\end{array}$} \\
\hline & & Tanggal & Jam & Tanggal & Jam & & \\
\hline MT. Ice Transporter & SPM & 10-Jan-18 & $15: 00$ & $\begin{array}{l}12-\text { Jan - } \\
18\end{array}$ & $11: 30$ & 44,5 & No Excess \\
\hline $\begin{array}{l}\text { MT. Dewi } \\
\text { Maeswara }\end{array}$ & SPM & 15-Jan-18 & $11: 12$ & $\begin{array}{l}18-\text { Jan - } \\
18\end{array}$ & $11: 30$ & 72,3 & Excess Lay Time \\
\hline MT. Delta Sky & SPM & 19-Jan-18 & $13: 00$ & $\begin{array}{l}21-\mathrm{Jan}- \\
18\end{array}$ & $8: 22$ & 43,4 & No Excess \\
\hline MT. Wafrah & CIB 2 & 02- Jan -18 & $15: 20$ & $\begin{array}{l}\text { 03- Jan - } \\
18\end{array}$ & $17: 00$ & 25,7 & No Excess \\
\hline MT. Bull Papua & CIB 2 & 05- Jan -18 & $15: 30$ & $\begin{array}{l}\text { 07- Jan - } \\
18\end{array}$ & 9:06 & 41,6 & Excess Lay Time \\
\hline \multirow[t]{2}{*}{ MT. Erawan 99} & CIB 2 & 08- Jan -18 & $15: 00$ & $\begin{array}{l}\text { 10- Jan - } \\
18\end{array}$ & $11: 03$ & 44,1 & Excess Lay Time \\
\hline & CIB 2 & 09- Jan -18 & $15: 42$ & $\begin{array}{l}10-\mathrm{Jan}- \\
18\end{array}$ & $11: 03$ & 19,4 & No Excess \\
\hline MT. Sanana & CIB 2 & 12- Jan -18 & $16: 00$ & $\begin{array}{l}\text { 13- Jan - } \\
18\end{array}$ & $16: 13$ & 24,2 & No Excess \\
\hline \multirow[t]{2}{*}{ MT. SC Warrior } & CIB 2 & 17- Jan -18 & $11: 00$ & $\begin{array}{l}\text { 19- Jan - } \\
18\end{array}$ & $11: 22$ & 48,4 & Excess Lay Time \\
\hline & CIB 2 & 18- Jan -18 & $10: 24$ & $\begin{array}{l}\text { 19- Jan - } \\
18\end{array}$ & $11: 22$ & 25,0 & No Excess \\
\hline \multirow[t]{2}{*}{ MT. Jag Leela } & CIB 1 & 21- Jan -18 & $21: 36$ & $\begin{array}{l}22-\mathrm{Jan}- \\
18\end{array}$ & $14: 43$ & 17,1 & No Excess \\
\hline & CIB 1 & 22- Jan -18 & $14: 24$ & $\begin{array}{l}23-\mathrm{Jan}- \\
18\end{array}$ & $14: 43$ & 24,3 & No Excess \\
\hline MT. Cakra Patriot & CIB 2 & 22- Jan -18 & $20: 30$ & $\begin{array}{l}25-\mathrm{Jan}- \\
18\end{array}$ & $8: 30$ & 60,0 & Excess Lay Time \\
\hline \multirow[t]{3}{*}{ MT. Bull Sulawesi } & CIB 2 & 28- Jan -18 & $21: 12$ & $\begin{array}{l}30-\text { Jan - } \\
18\end{array}$ & $6: 38$ & 33,4 & No Excess \\
\hline & CIB 2 & 28- Jan -18 & 22:00 & $\begin{array}{l}\text { 30- Jan - } \\
18\end{array}$ & $6: 38$ & 32,6 & No Excess \\
\hline & CIB 2 & 28- Jan -18 & 23:00 & $\begin{array}{l}\text { 29- Jan - } \\
18\end{array}$ & $16: 38$ & 17,6 & No Excess \\
\hline
\end{tabular}

Table 8 Perhitungan Excess Laytime Bulan Januari

\begin{tabular}{|c|c|c|c|c|c|c|c|}
\hline \multirow{2}{*}{ Vessel } & \multirow{2}{*}{ Sandar } & \multicolumn{2}{|c|}{ Start Discharge } & \multicolumn{2}{|c|}{ Hose Disconnected } & \multirow{2}{*}{$\begin{array}{l}\text { Lay Time } \\
\text { (Jam) }\end{array}$} & \multirow{2}{*}{$\begin{array}{l}\text { Lay Time } \\
\text { Analysis }\end{array}$} \\
\hline & & Tanggal & Jam & Tanggal & Jam & & \\
\hline MT. Dewi Maeswara & SPM & 03-Feb-18 & 13:00 & 06-Feb-18 & $7: 14$ & 66,2 & $\begin{array}{l}\text { Excess Lay } \\
\text { Time }\end{array}$ \\
\hline MT. Evgenia I & SPM & 13-Feb-18 & 13:00 & 15-Feb-18 & $6: 24$ & 41,4 & No Excess \\
\hline MT. Jag Leena & SPM & 18-Feb-18 & $15: 00$ & 20-Feb-18 & $7: 24$ & 40,4 & No Excess \\
\hline MT. SC Fortune XL & SPM & 20-Feb-18 & $14: 24$ & 23-Feb-18 & $10: 43$ & 68,3 & $\begin{array}{l}\text { Excess Lay } \\
\text { Time }\end{array}$ \\
\hline MT. Evgenia I & SPM & 23-Feb-18 & $11: 40$ & 25-Feb-18 & $17: 03$ & 53,4 & No Excess \\
\hline MT. Ocean Li & CIB 2 & 04-Feb-18 & 16:06 & 06-Feb-18 & $9: 10$ & 41,1 & $\begin{array}{l}\text { Excess Lay } \\
\text { Time }\end{array}$ \\
\hline & CIB 2 & 05-Feb-18 & $19: 12$ & 06-Feb-18 & $15: 10$ & 20,0 & No Excess \\
\hline MT. Galunggung & CIB 2 & 08-Feb-18 & $17: 10$ & 10-Feb-18 & $9: 42$ & 40,5 & $\begin{array}{l}\text { Excess Lay } \\
\text { Time }\end{array}$ \\
\hline & CIB 2 & 09-Feb-18 & $10: 00$ & 10-Feb-18 & $9: 42$ & 23,7 & No Excess \\
\hline MT. Cakra Patriot & CIB 2 & 10-Feb-18 & 21:00 & 12-Feb-18 & $8: 25$ & 35,4 & No Excess \\
\hline MT. SC Champion & CIB 2 & 12-Feb-18 & $20: 30$ & 14-Feb-18 & $17: 27$ & 45,0 & $\begin{array}{l}\text { Excess Lay } \\
\text { Time }\end{array}$ \\
\hline
\end{tabular}


Table 8 Perhitungan Excess Laytime Bulan Januari

\begin{tabular}{llllllll}
\hline MT. Erawan 99 & CIB 2 & 15-Feb-18 & $19: 00$ & 16-Feb-18 & $15: 55$ & 20,9 & No Excess \\
& CIB 2 & 16-Feb-18 & $10: 51$ & 17-Feb-18 & $7: 55$ & 21,1 & No Excess \\
MT. Gemini Sun & CIB 3 & 24-Feb-18 & $17: 00$ & 25-Feb-18 & $17: 41$ & 24,7 & No Excess \\
\hline
\end{tabular}

\subsection{Perhitungan Blending Component dengan Volume dan Octane Number (ON)}

Blending komponen yang dimasukkan memiliki karakteristik yang berbeda dengan spesifikasi yang berbeda pula. Data yang digunakan yaitu, volume dan Oktan Number (ON) komponen $P L$ 1, PL-2, Naphtha RFCC, L-Naphtha CDU II, L-Naphtha Ex. NHT 1, dan Mogas KPC. Harga produk Premium, Pertamax, Naphtha, LOMC (Low Octane Mogas Component), HOMC (High Octane Mogas Component). Kapasitas tangki Naphtha dibutuhkan untuk mempertimbangkan pengalokasian Naphtha yang digunakan. Tangki Naphtah yang digunakan yaitu 31T01, 31T2, 31T7, 71T21 dengan total kapasitas tangki 378,018 MB.

Table 9 Hasil Blending Produksi Maximize Premium

\begin{tabular}{|c|c|c|c|c|c|c|}
\hline Komponen & Stream Ex & SG & $\begin{array}{l}\text { Vol produksi } \\
\text { (MB/Bulan) }\end{array}$ & $\begin{array}{l}\text { Fraksi } \\
\text { Volume(\%) }\end{array}$ & ON & ON Blend \\
\hline PL-1 & Platformate-1 & 0,7486 & 353,43 & 0,14 & 87,65 & 12,60 \\
\hline PL-2 & Platformate-2 & 0,7434 & 575,48 & 0,23 & 91,50 & 21,42 \\
\hline $\begin{array}{l}\text { Naphtha } \\
\text { RFCC }\end{array}$ & RFCC & 0,7435 & $1.168,12$ & 0,48 & 92,52 & 43,97 \\
\hline $\begin{array}{l}\text { L-Naphtha } \\
\text { CDU II }\end{array}$ & CDU II & 0,7545 & 227,95 & 0,09 & 76,71 & 7,11 \\
\hline $\begin{array}{l}\text { L-Naphtha } \\
\text { Ex. NHT } 1\end{array}$ & NHT 1 & 0,6873 & 128,52 & 0,05 & 51,75 & 2,71 \\
\hline Mogas KPC & $\mathrm{KPC}$ & 0,8537 & 4,27 & 0,00 & 101,69 & 0,18 \\
\hline Total & & & $2.457,77$ & 1,00 & & 88,00 \\
\hline \multicolumn{3}{|c|}{ Excess Naphtha } & 49,36 & & & \\
\hline
\end{tabular}

Berdasarkan data diatas dapat kita ketahui total Premium yang diperoleh sebesar 2.457,77 MB atau 2.172.050 barrel. Dengan sisa Naphtha sebesar 49,36 MB atau 49.360 barrel. Perhitungan Revenue produksi Premium tersebut adalah sebagai berikut:

$$
\begin{gathered}
\text { Revenue }=(\text { Volume Premium } x \text { NRP })+(\text { Volume Naphtha } x \text { NRP }) \\
=(2.457 .770 \mathrm{bbl} \times 66,00 \mathrm{USD} / \mathrm{bbl})+(49.360 \mathrm{bbl} \times 63,08 \mathrm{USD} / \mathrm{bbl}) \\
=165.326 .387,48 \mathrm{USD}
\end{gathered}
$$

Table 10 Hasil Blending Produksi Maximize Pertamax

\begin{tabular}{lllllll}
\hline Komponen & Stream Ex & SG & $\begin{array}{l}\text { Vol produksi } \\
\text { (MB/Bulan) }\end{array}$ & $\begin{array}{l}\text { Fraksi } \\
\text { Volume(\%) }\end{array}$ & ON & ON Blend \\
\hline PL-1 & Platformate-1 & 0,7486 & 85,44 & 0,05 & 87,65 & 4,09 \\
PL-2 & Platformate-2 & 0,7434 & 575,48 & 0,31 & 91,50 & 28,72 \\
Naphtha RFCC & RFCC & 0,7435 & $1.168,12$ & 0,64 & 92,52 & 58,95 \\
LOMC & NaphthaBlending & 0,7209 & 0,00 & 0,00 & 65,77 & 0,00 \\
\hline
\end{tabular}


Table 10 Hasil Blending Produksi Maximize Pertamax

\begin{tabular}{|c|c|c|c|c|c|c|}
\hline Komponen & Stream Ex & SG & $\begin{array}{l}\text { Vol produksi } \\
\text { (MB/Bulan) }\end{array}$ & $\begin{array}{l}\text { Fraksi } \\
\text { Volume(\%) }\end{array}$ & $\mathrm{ON}$ & ON Blend \\
\hline Mogas KPC & KPC & 0,8537 & 4,27 & 0,00 & 101,69 & 0,24 \\
\hline Total & & & $1.833,31$ & 1,00 & & 92,00 \\
\hline Excess LOMC & & & 405,83 & & & \\
\hline ExcessNaphthah PL-1 & & & 267,99 & & & \\
\hline
\end{tabular}

Berdasarkan data diatas dapat kita ketahui total Pertamax yang diperoleh sebesar 1.833,31 MB atau 1.833.310 barrel. Dengan sisa Naphtha sebesar 405,83+267,99 $=673,82 \mathrm{MB}$ atau 673.820 barrel. Perhitungan Revenue produksi Premium tersebut adalah sebagai berikut:

$$
\begin{gathered}
\text { Revenue }=(\text { Volume Pertamax } x \text { NRP })+(\text { Volume Naphtha } \times \text { NRP }) \\
=(1.833 .310 \mathrm{bbl} \times 78,88 \mathrm{USD} / \mathrm{bbl})+(673.820 \mathrm{bbl} \times 63,08 \mathrm{USD} / \mathrm{bbl}) \\
=187.115 .940,49 \mathrm{USD}
\end{gathered}
$$

\subsection{Evaluasi Perbaikan pada Proses Pemurnian (Refinery) pada PERTAMINA (Persero) RU IV Cilacap}

Harga merupakan parameter utama yang berpengaruh terhadap margin pada PERTAMINA (Persero) RU IV Cilacap. Semakin tinggi harga impor dari minyak mentah maka nilai dari GPW dan Margin akan berbanding terbalik. Harga diperoleh berdasarkan kesepakatan yang telah di setujui oleh importir dan produsen minyak. Harga juga dipengaruhi oleh jarak transportasi yang ditempuh untuk mendistribusikan minyak mentah pada unit - unit pemurnian. Biaya tersebut ditambah dengan keterlambatan pengiriman yang dilakukan oleh produsen dan memberikan

dampak biaya excess laytime pada importir minyak mentah. Hal tersebut dikarenakan keterlambatan minyak menyebabkan importir harus membayar denda penyewaan (Demurrage). Perbaikan dapat dilakukan dengan cara Design, Source, Make, Deliver dan Return pada Supply Chain. Untuk mengatasi turbulensi pada rantai pasok maka dapat diatasi dengan Resilient Supply Chain[5]. 


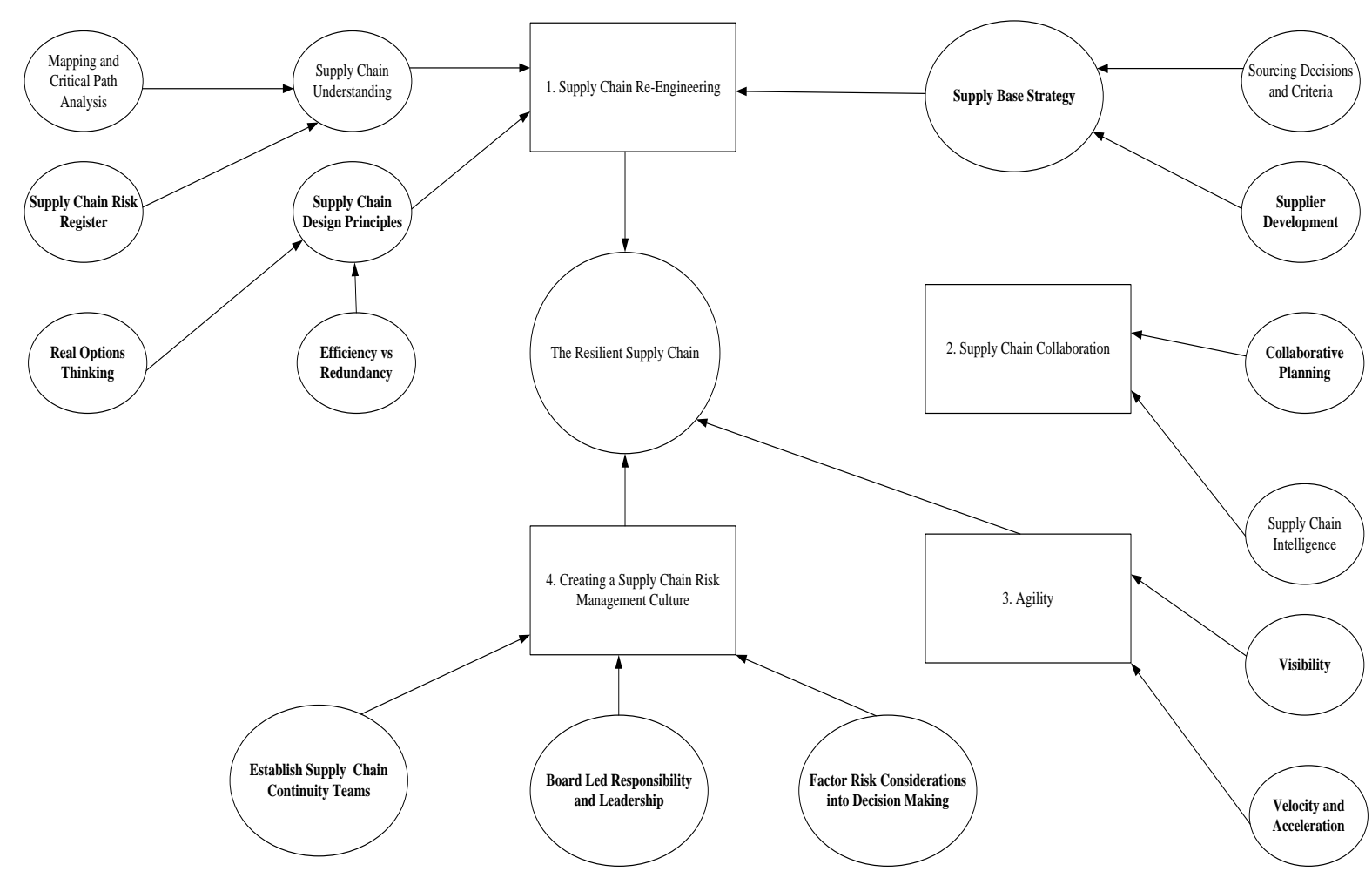

Figure 1 Resilient Supply Chain

\section{Kesimpulan Dan Saran}

a. Jumlah crude yang memenuhi karateristik dengan batasan nilai sulfur $\leqslant 0,2 \%$ dan nilai Gross Product Worthdan Marginpositif untuk Bulan Januari dan Februari berjumlah 27 crude.

b. Simulasi Berthing Time mengalami keterlambatan dikarenakan hal - hal seperti : Ketersediaan Loading Port yang tidak memadai, Toleransi dari Bill of Lading (B/L) dari alokasi kargo sebesar $\pm 5-10 \%$ volume crude maupun dampak terbesar disebabkan oleh keterlambatan pendistribusian yang berasal dari produsen minyak mentah.

c. Blending dilakukan untuk memperoleh Octane Number $(\mathrm{ON})$ yang paling optimal agar sebanding dengan revenue yang didapatkan. Blending penting dkarenakan minyak mentah di Indonesia tidak dapat bertahan hanya dengan memanfaatkan minyak mentah yang berasal dari Timur Tengah namun diharuskan adanya inovasi baru dengan menggunakan crude domestic yang tersedia.

d. Kolaborasi dilakukan dengan menggunakan Resilient Supply Chain. Bahwa harus terdapat kolaborasi aktif diantara pada pelaku rantai pasok baik bagi produsen maupun importir dalam hal ini Indonesia. 


\section{REFERENSI}

[1] Doshi, Tilak K. dan D’Souza ,Neil Sebastian., 2011, “The Asia Premium in Crude Oil Markets and Energy Market Integration”. Energy Studies Institute, National University of Singapore.

[2] Surinfer, Parkash., 2003, "Refining Processes Handbook”. Gulf Professional Publishing.

[3] Yamaguchi, Dr. Nancy., "WTI and Brent Crudes : Trans Atlantic Cousins Re-Eamine their Relationship Part 1".

[4] Manzano, Baltasar., "Oil Subsidies and Renewable Energy in Saudi Arabia : A General Equilibrium Approach".

[5] Cristoper, Martin., 2011."Logistic and Supply Chain Management”. Prentice Hall. 